\title{
The Effectiveness of Surgery-Based Treatment in Advanced Oropharyngeal Cancers
}

\author{
Young-Chan Kim ${ }^{\mathbb{D}}$, Hyeongeun Kim, Jiwon Kwak, Hoyoung Lee, \\ Kwang-Yoon Jung, and Seung-Kuk Baek \\ Department of Otorhinolaryngology-Head and Neck Surgery, Korea University College of Medicine, Seoul, Korea
}

\author{
진행된 구인두암에서 수술 기반 치료의 효과 \\ 김영찬 · 김현근 - 곽지원 · 이호영 · 정광윤 - 백승국 \\ 고려대학교 의과대학 이비인후-두경부외과학교실
}

Received October 21, 2020

Revised December 17, 2020

Accepted December 18, 2020

Address for correspondence

Seung-Kuk Baek, MD, PhD

Department of Otorhinolaryngology-

Head and Neck Surgery,

Korea University

College of Medicine,

73 Goryeodae-ro, Seongbuk-gu,

Seoul 02841, Korea

Tel $+82-2-920-5486$

Fax $+82-2-925-5233$

E-mail mdskbaek@gmail.com
Background and Objectives Oropharyngeal cancers (OPCs) can be staged down to a lower stage with p16 positivity and de-escalated therapy has been the common practice. The aim of this study is to evaluate the survival outcomes based on various clinical factors in advanced OPC patients.

Subjects and Method A total of 58 OPC patients in the stage IVA based on the American Joint Committee on Cancer 7th edition were treated with primary surgery or primary chemoradiation therapy from 2010 to 2016. A survival analysis was carried out using the KaplanMeier method, log-rank test, and Cox proportional hazards model.

Results The median follow-up was 39.5 months. Thirty-eight and 20 patients received surgery-based and radiation therapy (RT)-based treatments, respectively. Clinical T-stage and treatment method were significant risk factors for 5-year disease-free survival (DFS) rate, and the treatment method was the only significant risk factor for overall-survival (OS) rate. 5-year DFS rate in the surgery-based treatment and RT-based treatment was $76.1 \%$ and $36.0 \%(p=0.001)$. On multivariate analysis, the surgery-based treatment group was associated with a significantly reduced hazard of death [the hazard ratio (HR) for the radiation-based treatment was 6.565 compared to the surgery-based treatment, $p=0.002]$. 5-year OS rate in the surgery-based treatment and RT-based treatment was $91.1 \%$ and $53.4 \%(p=0.003)$, respectively. On the multivariate analysis, the surgery-based treatment group was associated with a significantly reduced hazard of death (the HR for the radiation-based treatment was 7.544 compared to the surgerybased treatment, $p=0.012$ ).

Conclusion The primary surgery-based treatment for advanced OPC showed a better survival outcome than the primary radiation-based treatment, irrespective of p16 positivity. Korean J Otorhinolaryngol-Head Neck Surg 2021;64(7):486-90

Key Words Chemoradiotherapy · Comparative study · Oropharyngeal neoplasms · Surgery $\cdot$ Survival rate.

\begin{abstract}
서 론
구인두암은 다른 두경부암과 달리 흡연율의 감소에도 유병 률이 세계적으로 증가추세에 있는 암으로, human papillo-

ma virus(HPV)가 유병률 증가의 원인으로 생각된다.') 아시 아에서 HPV와 관련된 구인두암의 증가가 명확히 확립되지는 않았지만, 서양의 경우, 연구에 따라 $70 \%$ 의 구인두암이 $\mathrm{HPV}$ 양성이다. ${ }^{2)}$ 이러한 HPV로 인해 발생한 구인두암에서는 p16
\end{abstract}

This is an Open Access article distributed under the terms of the Creative Commons Attribution Non-Commercial License (https://creativecommons.org/licenses/by-nc/4.0) which permits unrestricted non-commercial use, distribution, and reproduction in any medium, provided the original work is properly cited. 
과발현이 확인되고, 이러한 p16 양성의 구인두암 환자들의 상 대적으로 높은 생존율은 p16 양성 구인두암의 병기를 낮추고, 치료의 강도를 낮추게 하였다. American Joint Committee on Cancer(AJCC) 7판의 구인두암 예후 병기 설정에서 병기 IVA로 분류되던 TNM 병기의 암들이 AJCC 8판에서 p16 양 성인 경우, 병기 II, III으로 분류된다. 치료와 관련해서도 2020 년 NCCN Guidelines의 치료에서 p16 양성의 T4a 또는 N3의 국소적 또는 구역적으로 진행된 구인두암의 경우 항암방사선 치료/방사선 치료가 수술을 우선시하는 치료보다 더 좋다고 명시하고 있다.) 이는 항암방사선 치료/방사선 치료와 수술을 우선시하는 치료가 비슷한 생존율을 갖지만, 수술의 경우가 치료 관련 합병증 이환율이 높기 때문인 것으로 설명하고 있 다. ${ }^{47)}$ 하지만 타 연구에서는 수술을 우선시하는 치료가 방사 선기반 치료를 우선으로 하는 치료보다 생존율이 좋으며, ${ }^{8}$ 방 사선기반 치료의 경우, 치료 후 5년이 경과되면 치료 관련 합 병증이 반 이상의 환자들에서 나타나고, 항암치료를 같이 받 는 경우 합병증 발생 위험도가 3.24에서 4.40배 높다고 주장 하고 있다."

이와 같은 국소 진행성 구인두암에서의 치료 방침에 대한 이견 분석을 위해 AJCC 7판에서 병기 IVA로 분류됐던 국 소 진행성 구인두암에서 실제로 생존율에 영향을 주는 요인 들을 알아보고, 생존율과 관련된 수술의 영향을 알아보고자 한다.

\section{대상 및 방법}

\section{대 상}

본 연구는 후향적 코호트 연구로 2010년 1월 1일 2016년 12월 31일까지 AJCC 7판을 기준으로, 조직학적으로 구인두 편평상피세포암 병기 IVA를 진단받은 환자 73명을 대상으로 하였다. 이 중 의무기록이 불충분하거나, 구인두암의 진단 전 또는 진단과정에서 다른 부위 원발암이 진단되거나, 다른 의 료기관에서 치료나 수술만 받고 추가적인 보조 치료를 받지 못한 15 명의 환자를 연구에서 제외하였다. 최종적으로 58 명 의 환자를 대상으로 하여 진단 시 나이, 성별, TNM 병기, p16 검사결과, 주 치료방법, 생존기간, 추적 관찰 기간 등의 임상 정보에 대해 조사하였다.

이 연구는 본 의료기관의 의학연구 윤리심의위원회(IRB 2015AN0258)의 승인을 받았다.

\section{치료방법}

주 치료 방법에 따라 수술치료 군과 방사선치료 군으로 분 류하였다. 총 38 명의 수술치료 군 중에서 32 명에서 경구강 광
범위 절제술을 시행했고, 2 명은 외측 인두절개술, 3 명은 경하 악골 접근을 이용한 절제술, 1 명은 경부를 통하여 pull through 접근법을 이용한 절제술을 하였다. 32 명의 경구강 광범위 절 제술 환자 중에서 13 명은 경구강 로봇수술을 받았다. 38 명 중에서 경구강 절제술 외의 6 명의 환자들 모두 유리피판 재 건술을 받았고, 경구강 절제술 환자들 중 1 명은 국소피판 재 건술을 받았다. 38 명의 수술 기반의 치료를 받은 환자에서 41 측의 선택적 경부 절제술을 시행했고, 치료적 경부 절제술이 40 측, 예방적 경부 절제술이 1측이었다. 방사선 용량은 수술 기반의 치료 군에서는 주로 $6000 \mathrm{cGy}$ 이상을 하루에 $180 \mathrm{cGy}$ 씩, 방사선 기반의 치료 군에서는 주로 $7000 \mathrm{cGy}$ 이상을 하 루에 $180 \mathrm{cGy}$ 씩 분할조사하는 방식으로 조사하였다. 방사선 기반의 치료 군에서 3 명은 방사선 치료 단독으로 시행 받고, 17 명은 항암방사선 병용 요법을 시행 받았다. 방사선치료와 동반하는 항암치료는 cisplatin $30 \mathrm{mg} / \mathrm{m}^{2}$ 를 매주 투여하여, 총 7주간 투여하는 것을 표준으로 하였다. 13 명에서 선행화학 요법을 시행하였는데 치료 후 반응 평가에 따라 9명은 수술, 4 명은 항암방사선치료를 하였다. 선행화학요법은 cisplatin $60 \mathrm{mg} / \mathrm{m}^{2}$ 과 docetaxel $65 \mathrm{mg} / \mathrm{m}^{2}$ 을 3주 간격으로 2회 투여 후 반응 평가하는 것을 표준으로 하였다. 구제수술과 관련해 서 38 명의 수술 기반 치료 군에서는 5 명의 환자에서 구제수 술을 했고, 20 명의 방사선 기반 치료 군에서는 6 명의 환자에 서 구제수술을 했다.

\section{분석 방법}

주 치료방법과 다른 임상 인자들의 연관성 검정을 위해 Fisher의 정확한 검정을 사용했다. 생존율 분석을 위해 $\mathrm{Ka}^{-}$ plan-Meier 방법을 사용하였고, 각 인자별 생존율 차이의 유 의성 검증을 위해 Log-rank test를 통해서 통계적 유의성을 확인하였고, $\operatorname{Cox}$ 비례위험모형으로 다변수 생존율 분석을 통해 비례위험도(hazard ratio)를 구하였다.

데이터의 통계분석은 SPSS(version 22.0 for windows; IBM Corp., Armonk, NY, USA)를 이용했으며, 유의 수준이 0.05 미만인 경우를 통계적으로 유의한 것으로 판정하였다.

\section{결 과}

대상 환자의 추적 관찰 중앙값은 39.5 개월이었다. 연령분포 는 36 82세까지였고, 60세 미만이 29명(50\%), 60세 이상이 29명(50\%)이었다. 남자는 56명(96.6\%)이었고, 여자는 2명 (3.4\%)이었다. 이 중에서 38명(65.5\%)이 수술 기반의 치료를 받았고, 20명(34.5\%)은 방사선 기반의 치료를 받았다. 임상적 T병기는 T1, T2가 30명(51.7\%), T3, T4가 28명(48.3\%)이었 
고, 임상적 N병기는 N0, N1이 5명(8.6\%), N2가 53명(91.4\%)이 었다. p16 검사 결과가 없는 사람은 28명(48.3\%), 음성인 사람 11 명(19.0\%), 양성인 사람 19명(32.8\%)이었다. 치료방법에 따 라 나눈 두 군을 비교하였을 때 여러 임상 인자들의 통계학 적인 차이는 없었다(Table 1).

단변수 생존율 분석에서 5년 무병 생존율(disease-free survival)은 여러 임상 인자 중에 T병기, 주 치료방법에 의해서만 유의한 차이를 보였고(Table 2), 질병 특이 생존율(diseasespecific overall survival)은 주 치료방법에 의해서만 유의한 질병 특이 생존율의 차이를 보였다(Table 3). 주 치료방법에 따른 5년 무병 생존율을 보면, 주 치료법이 수술인 경우, 5년 무병 생존율이 $76.1 \%$ 이고, 주 치료방법이 방사선 기반인 경 우, 5년 무병 생존율이 $36.0 \%$ 이었다( $p=0.001$ )(Fig. 1A). 주 치료 방법에 따른 5년 질병 특이 생존율을 보면, 주 치료법이 수술인 경우, 5년 생존율이 $91.1 \%$ 이고, 주 치료방법이 방사선 기반인 경우, 5년 생존율이 53.4\%이었다( $p=0.003)(F i g .1 B)$.

다변수 생존율 분석에서 무병 생존율은 단변수 생존율 분 석과 마찬가지로 $\mathrm{T}$ 병기, 주 치료 방법에서 유의한 차이를 보 였다(Table 2). 그 외에도, 무병 생존율의 경우, p16 음성인 경 우가 p16 검사를 하지 않은 군보다 유의하게 비례위험도가 4.078로 높았다 $(p=0.042)$. 반면, $\mathrm{p} 16$ 양성인 경우는 $\mathrm{p} 16$ 검사

Table 1. Clinical characteristics of the patients

\begin{tabular}{lcrrr}
\hline Characteristics & $\begin{array}{c}\text { No. of } \\
\text { patients (\%) }\end{array}$ & $\begin{array}{c}\text { OP+RT/ } \\
\text { CCRT (\%) }\end{array}$ & $\begin{array}{c}\text { RT/CCRT } \\
(\%)\end{array}$ & p value \\
\hline Age & & & & 0.408 \\
$<60$ & $29(50.0)$ & $17(58.6)$ & $12(41.4)$ & \\
$\geq 60$ & $29(50.0)$ & $21(72.4)$ & $8(27.6)$ & \\
Sex & & & & $>0.999$ \\
Male & $56(96.6)$ & $37(66.1)$ & $19(34.0)$ & \\
Female & $2(3.4)$ & $1(50.0)$ & $1(50.0)$ & \\
Clinical T stage & & & & 0.097 \\
T1-2 & $30(51.7)$ & $23(76.7)$ & $7(23.3)$ & \\
T3-4 & $28(48.3)$ & $15(53.6)$ & $13(46.6)$ & \\
Clinical N stage & & & & 0.650 \\
N0-1 & $5(8.6)$ & $4(80.0)$ & $1(20.0)$ & \\
N2 & $53(91.4)$ & $34(64.2)$ & $19(35.8)$ & \\
P16 & & & & $>0.999$ \\
N/A & $28(48.3)$ & $14(50.0)$ & $14(50.0)$ & \\
Negative & $11(19.0)$ & $9(81.8)$ & $2(18.2)$ & \\
Positive & $19(32.8)$ & $15(78.9)$ & $4(21.2)$ &
\end{tabular}

Thirty-eight and 20 patients received surgery- and RT-based treatments, respectively. $p$ values from Fisher's exact tests showed that there were not any significant association between the therapy and other factors. OP: surgery, RT: radiation therapy, CCRT: concurrent chemoradiotherapy, N/A: not available
를 하지 않은 군보다 비례위험도가 2.281배로 높았으나, 유의 하지는 않았다 $(p=0.194)$. 또한, $\mathrm{p} 16$ 결과가 있는 환자들만을 대상으로 무병 생존율에 대하여 다변수 분석을 했을 때도 $\mathrm{p} 16$ 음성인 경우가 양성인 경우에 비해 비례위험도가 2.811 (95\% 신뢰구간: $0.634 ~ 12.452)$ 이었으나, 유의하지 않았다 $(p=$ 0.174). 한편, 주치료방법이 수술일 때에 비해서 방사선 기반 의 치료를 받았을 때 무병 생존율 관련 비례위험도는 6.565 이었다 $(p=0.002)$ (Table 2). 질병 특이 생존율은 주치료방법에 의해서만 유의한 생존율의 차이를 보였고, 주치료방법이 수 술일 때에 비해서 방사선 기반의 치료를 받았을 때 비례위험 도가 7.544이었다 $(p=0.012)$ (Table 3).

\section{고 찰}

본 연구에서는 2010 2016년까지 7년간 치료한 병기 IVA 구인두암 환자를 대상으로 여러가지 임상적인 인자에 따른 치료 결과를 분석한 결과 수술 기반 치료를 받은 환자들이 비수술 기반 치료를 받은 환자들보다 무병 생존율과 질병 특 이 생존율이 우수하다는 결과를 얻었다.

이전 발표된 1996 2002년까지 119명의 병기 III, IV의 두

Table 2. Univariate and multivariate disease-free survival analysis of characteristics in patients with stage IVA oropharyngeal squamous cell carcinoma

\begin{tabular}{|c|c|c|c|c|}
\hline \multirow[b]{2}{*}{ Characteristics } & \multicolumn{2}{|c|}{ Univariate } & \multicolumn{2}{|l|}{ Multivariate } \\
\hline & $\begin{array}{c}\text { 5-year } \\
\text { survival } \\
(\%)\end{array}$ & p value & $\begin{array}{l}\text { Hazard } \\
\text { ratio } \\
(95 \% \mathrm{Cl})\end{array}$ & $p$ value \\
\hline Age & & 0.217 & & \\
\hline$<60$ & 52.9 & & Reference & \\
\hline$\geq 60$ & 76.6 & & $0.842(0.268,2.644)$ & 0.769 \\
\hline Sex & & 0.329 & & \\
\hline Male & 61.9 & & Reference & \\
\hline Female & 100.0 & & N/A & 0.987 \\
\hline Clinical T stage & & 0.002 & & \\
\hline $\mathrm{T} 1-2$ & 85.0 & & Reference & \\
\hline $\mathrm{T} 3-4$ & 34.6 & & $3.614(1.049,12.451)$ & 0.042 \\
\hline Clinical N stage & & 0.711 & & \\
\hline No-1 & 60.0 & & Reference & \\
\hline N2 & 64.2 & & $0.878(0.152,5.080)$ & 0.884 \\
\hline pl6 & & 0.514 & & \\
\hline N/A & 72.7 & & Reference & \\
\hline Negative & 54.5 & & $4.078(1.055,15.762)$ & 0.042 \\
\hline Positive & 51.6 & & $2.281(0.656,7.925)$ & 0.194 \\
\hline Treatment metho & & 0.001 & & \\
\hline $\mathrm{OP}+\mathrm{RT} / \mathrm{CCRT}$ & 76.1 & & Reference & \\
\hline RT/CCRT & 36.0 & & $6.565(1.959,21.997)$ & 0.002 \\
\hline
\end{tabular}

$\mathrm{Cl}$ : confidence interval, N/A: not available, OP: surgery, RT: radiation therapy, CCRT: concurrent chemoradiotherapy 
경부암 환자를 대상으로 한 연구에서는 구인두암 환자들에 서는 수술 기반의 치료와 방사선 기반의 치료에서 5년 생존 율에 유의미한 차이가 없었다. ${ }^{10)}$ 하지만 미국에서 2004 2013 년까지 22676명의 병기 III, IV의 구인두암 환자를 대상으로 한 연구에서는 수술 기반의 치료와 방사선 기반의 치료 각각

Table 3. Univariate and multivariate disease-specific overall survival analysis of characteristics in patients with stage IVA oropharyngeal squamous cell carcinoma

\begin{tabular}{|c|c|c|c|c|}
\hline \multirow[b]{2}{*}{ Characteristics } & \multicolumn{2}{|c|}{ Univariate } & \multicolumn{2}{|l|}{ Multivariate } \\
\hline & $\begin{array}{l}\text { 5-year } \\
\text { survival } \\
(\%)\end{array}$ & p value & $\begin{array}{c}\text { Hazard } \\
\text { ratio } \\
(95 \% \mathrm{Cl})\end{array}$ & $p$ value \\
\hline Age & & 0.571 & & \\
\hline$<60$ & 74.3 & & Reference & \\
\hline$\geq 60$ & 84.3 & & $1.373(0.330,5.710)$ & 0.663 \\
\hline Sex & & 0.480 & & \\
\hline Male & 77.8 & & Reference & \\
\hline Female & 100.0 & & N/A & 0.990 \\
\hline Clinical T stage & & 0.084 & & \\
\hline $\mathrm{T} 1-2$ & 86.9 & & Reference & \\
\hline Т3-4 & 69.2 & & $2.390(0.564,10.115)$ & 0.237 \\
\hline Clinical N stage & & 0.930 & & \\
\hline No-1 & 80.0 & & Reference & \\
\hline N2 & 78.8 & & $1.103(0.112,10.855)$ & 0.933 \\
\hline p16 & & 0.736 & & \\
\hline N/A & 76.7 & & Reference & \\
\hline Negative & 77.0 & & $2.400(0.496,11.617)$ & 0.276 \\
\hline Positive & 90.9 & & $1.013(0.106,9.644)$ & 0.991 \\
\hline Treatment metho & & 0.003 & & \\
\hline OP+RT/CCRT & 91.1 & & Reference & \\
\hline RT/CCRT & 53.4 & & $7.544(1.573,36.180)$ & 0.012 \\
\hline
\end{tabular}

Treatment method was the only significant factor affecting survival both in univariate $(p=0.003)$ and multivariate $(p=0.012)$ analysis. $\mathrm{Cl}$ : confidence interval, N/A: not available, OP: surgery, RT: radiation therapy, CCRT: concurrent chemoradiotherapy
의 3년 생존율이 $85.4 \%$ 와 $72.6 \%(p<0.0001)$ 로 유의미한 차 이가 있었고, 다변수 분석에서 수술 기반의 치료가 방사선 기 반의 치료보다 보완된 비례위험도 $0.76(95 \%$ 신뢰구간, 0.72 , $0.81 ; p<0.0001)$ 이었다. 또한, HPV 감염 여부와 무관하게 수 술적 치료가 더 우수한 치료 결과를 보였다. ${ }^{8)}$

본 연구에서도 이와 같이 $\mathrm{p} 16$ 을 포함하여, 환자의 연령, 성 별, T병기, $\mathrm{N}$ 병기에 무관하게 수술 기반의 치료법이 방사선 기반의 치료법보다 우수한 생존율을 보였다. 그 이유로는 최 근 경구강 로봇 절제술(TORS)을 포함한 경구강 최소침습수 술의 발전과 피판을 이용한 재건 수술의 발전으로 인한 수술 관련 합병증 이환율의 감소가 수술 기반 치료의 생존율 향상 을 이끌었을 것으로 생각할 수 있다.

그 외의 변수들에 대해서 살펴보면, $\mathrm{T}$ 병기와 $\mathrm{N}$ 병기 모두 질병 특이 생존율에서는 유의미한 차이를 보이지 못했지만, $\mathrm{T}$ 병기는 무병 생존율에서는 단변수 분석 $(p=0.002)$ 과 다변수 분석 $(p=0.042)$ 모두에서 유의미한 예후의 차이를 보였다. 하 지만, $\mathrm{N}$ 병기는 무병 생존율 단변수 분석 $(p=0.711)$ 과 다변수 분석 $(p=0.884)$ 에서도 유의미한 차이를 보이지 못했다. 일반적 으로 암의 병기 설정과 관련하여 국소적 병기 외에 림프절의 전이정도도 예후에 중요한 인자이지만, 본 연구는 병기 IVA 환자들을 대상으로 하였기 때문에 NO-1에 속하는 환자 군의 수가 전체 58명 중에서 5명으로 특히 적어서 유의미하지 않게 나온 것으로 생각한다. 또다른 구인두암의 예후인자인 $\mathrm{p} 16$ 에 대해서 살펴보면, 다변수 분석에서 $\mathrm{p} 16$ 양성인 환자들과 비교 했을 때, p16 음성인 환자들의 무병 생존율과 질병 특이 생존 율 비례위험도가 높았지만 통계적으로 두 군의 차이가 유의 미하지는 않았다. 이는 본 연구에서 전체적인 연구 대상 환자 수가 적은 것 외에도, 검사결과가 없는 환자가 $48.3 \%$ 로 높아 서 발생한 것으로 생각한다. 이러한 결과는 p16 검사가 활성 화되지 않던 기간이 연구기간에 포함된 연구에서 나타나는 것
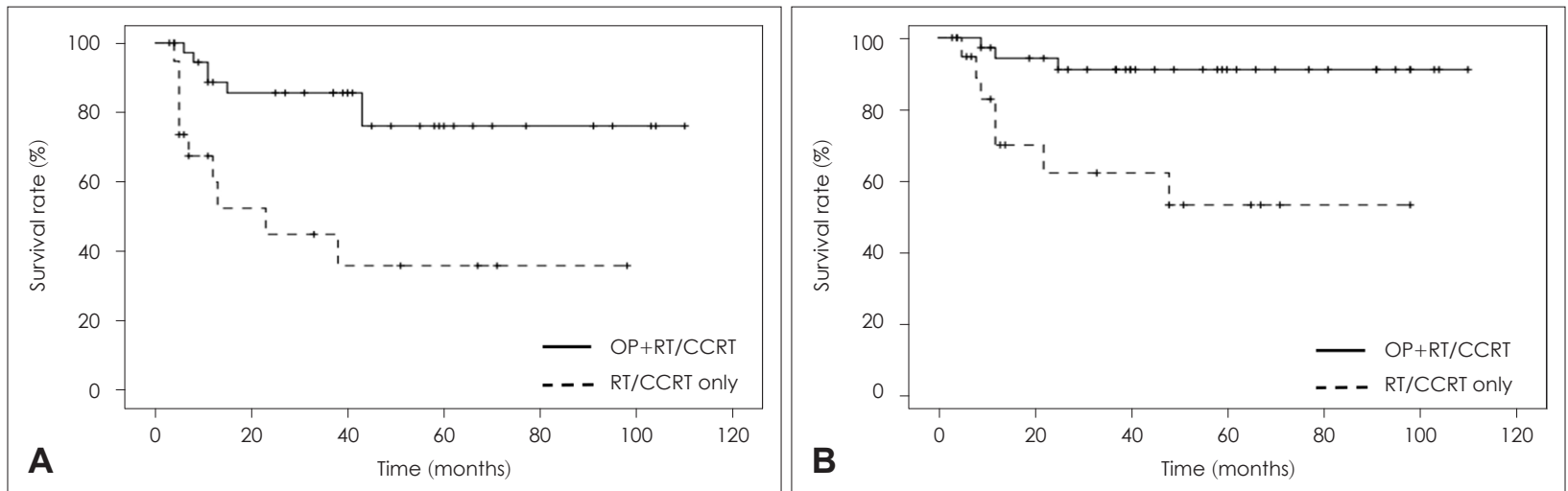

Fig. 1. DFS (A) and disease-specific overall survival $(B)$ curves according to treatment methods. DFS rates and overall survival rates were significantly different between surgery-based therapy group and radiation-based therapy group. OP: surgery, RT: radiation therapy, CCRT: concurrent chemoradiotherapy, DFS: disease-free survival. 
으로, 우리나라에서 2019년에 발표된 2004 2017년까지 135명

의 구인두암 환자들을 대상으로 한 연구에서도 $52.6 \%$ 에서 $\mathrm{p} 16$ 검사결과가 없었고, $\mathrm{p} 16$ 양성 환자 군에 비해 $\mathrm{p} 16$ 음성 환자 군에서 생존율은 낮았지만, 통계적으로 유의하지는 않았다. ${ }^{11}$ 국내에서 모든 병기의 구인두암에서 주 치료방법에 따른 생 존율 연구에서 135 명을 대상으로 추적 관찰 기간 중앙값이 33.8 개월이었음을 고려할 때, 본 연구는 병기 IVA 환자만으로 제한하여 58명을 대상으로 추적 관찰 기간 중앙값 39.5 개월 을 갖는다는 특징이 있다. ${ }^{11)}$ 이는 미국에서 진행한 대규모 연 구에서 추적 관찰 기간 중앙값이 40.7개월이었음을 고려할 때 에도 비교할 만한 수치이다. ${ }^{8)}$

본 연구에는 몇 가지 제한점이 있다. 연구대상자의 수가 적 어서 주 치료방법과 종양의 $\mathrm{T}$ 병기 외에 다른 변수들에서 유 의한 결과들을 얻어내기 어려웠고 무작위 대조 시험(randomized controlled trial)이 아닌 코호트 연구임으로서 발생 할 수 있는 주 치료방법과 다른 임상 인자들의 연관성 및 그 에 따른 잠재적 편향의 가능성이다. 또한, $\mathrm{p} 16$ 양성/음성과 관 련해 예후에 유의미한 차이를 얻지 못한 것과 관련해서는 검 사결과가 없는 환자가 $48.3 \%$ 으로 높아서 발생한 것으로 생각 된다.

결론적으로, 본 연구에서는 p16을 포함하여, 환자의 연령, 성별, $\mathrm{T}$ 병기, $\mathrm{N}$ 병기에 무관하게 수술 기반의 치료법이 방사선 기반의 치료법보다 생존율이 좋다는 결과를 얻을 수 있다. 추후 연구에서는 이상의 제한점을 보완하며 생존율뿐만 아 니라 발화기능과 연하기능을 포함하는 기능적 평가와 주관적 으로 미용성을 평가하는 것도 포함해서 연구한다면 구인두 암의 치료 방침 결정에 유용한 정보를 줄 수 있을 것이다.

\section{Supplementary Materials}

The Data Supplement is available with this article at https://doi. org/10.3342/kjorl-hns.2020.00990.

\section{Acknowledgments}

This study was supported by the Clinical Trial Center of Korea University Anam Hospital (I1502411), the Korea Health Technology R\&D Project (H14C0748) through the Korea Health Industry Development Institute (KHIDI) of the Ministry of Health \& Welfare, and the Basic Science Research Program through the National Research Foundation of Korea (NRF) funded by the Ministry of Education (NRF2018R1D1A1A09083263, 2020R1I1A1A01072499).

\section{Author Contribution}

Conceptualization: Young-Chan Kim, Seung-Kuk Baek. Data curation: Young-Chan Kim, Hyeongeun Kim, Jiwon Kwak, Hoyoung Lee. Formal analysis: Young-Chan Kim, Seung-Kuk Baek. Funding acquisition: Young-Chan Kim. Investigation: Young-Chan Kim. Methodology: Young-Chan Kim, Seung-Kuk Baek. Project administration: Seung-Kuk Baek. Software: Young-Chan Kim. Supervision: Seung-Kuk Baek. Validation: Young-Chan Kim. Visualization: Young-Chan Kim. Writing - original draft: Young-Chan Kim. Writing - review \& editing: Young-Chan Kim, Kwang-Yoon Jung, Seung-Kuk Baek.

\section{ORCIDs}

Seung-Kuk Baek https://orcid.org/0000-0002-4751-0337

Young-Chan Kim https://orcid.org/0000-0001-9510-1354

\section{REFERENCES}

1) Siegel RL, Miller KD, Jemal A. Cancer statistics, 2016. CA Cancer J Clin 2016;66(1):7-30.

2) Pytynia KB, Dahlstrom KR, Sturgis EM. Epidemiology of HPVassociated oropharyngeal cancer. Oral Oncol 2014;50(5):380-6.

3) Pfister DG, Spencer S, Adelstein D, Adkins D, Anzai Y, Brizel DM, et al. Head and neck cancers, version 2.2020, NCCN Clinical Practice Guidelines in oncology. J Natl Compr Canc Netw 2020; 18(7):873-98.

4) Parsons JT, Mendenhall WM, Stringer SP, Amdur RJ, Hinerman RW, Villaret DB, et al. Squamous cell carcinoma of the oropharynx: Surgery, radiation therapy, or both. Cancer 2002;94(11):2967-80.

5) Allal AS, Nicoucar K, Mach N, Dulguerov P. Quality of life in patients with oropharynx carcinomas: Assessment after accelerated radiotherapy with or without chemotherapy versus radical surgery and postoperative radiotherapy. Head Neck 2003;25(10):833-9; discussion 839-40.

6) Garden AS, Kies MS, Morrison WH, Weber RS, Frank SJ, Glisson BS, et al. Outcomes and patterns of care of patients with locally advanced oropharyngeal carcinoma treated in the early 21 st century. Radiat Oncol 2013;8:21.

7) Boscolo-Rizzo P, Stellin M, Fuson R, Marchiori C, Gava A, Da Mosto MC. Long-term quality of life after treatment for locally advanced oropharyngeal carcinoma: Surgery and postoperative radiotherapy versus concurrent chemoradiation. Oral Oncol 2009; 45(11):953-7.

8) Kamran SC, Qureshi MM, Jalisi S, Salama A, Grillone G, Truong MT. Primary surgery versus primary radiation-based treatment for locally advanced oropharyngeal cancer. Laryngoscope 2018; 128(6):1353-64

9) Dong Y, Ridge JA, Li T, Lango MN, Churilla TM, Bauman JR, et al. Long-term toxicities in 10-year survivors of radiation treatment for head and neck cancer. Oral Oncol 2017;71:122-8.

10) Iyer NG, Tan DS, Tan VK, Wang W, Hwang J, Tan NC, et al. Randomized trial comparing surgery and adjuvant radiotherapy versus concurrent chemoradiotherapy in patients with advanced, nonmetastatic squamous cell carcinoma of the head and neck: 10year update and subset analysis. Cancer 2015;121(10):1599-607.

11) Kang Y, Park H, Jung WJ, Ahn SH. Primary treatment and survival outcomes in oropharyngeal cancer. Korean J OtorhinolaryngolHead Neck Surg 2019;62(1):49-56. 
Supplementary Table 1. Operations for T3 and T4 patients

\begin{tabular}{|c|c|c|c|}
\hline CT & $\mathrm{CN}$ & Operations & Flap \\
\hline $4 a$ & 2 & Transoral robotic wide excision of BOT cancer (R), SND (R) (level II, III), (L) (level II, III, IV) & None \\
\hline $4 a$ & 2 & Radical resection of oropharynx \& BOT (R) via mandibular swing approach, MRND (B) & ALT free flap reconstruction \\
\hline $4 a$ & 2 & Hemiglossectomy (R) (mandibulotomy approach), SND (R) (level I, II, III, IV) & RFFF reconstruction \\
\hline $4 a$ & 2 & Robot assisted transoral oropharyngectomy (R), SND (R) (level II, III, IV) & None \\
\hline 3 & 2 & Wide excision of soft palate cancer (L), MRND (L) & $\begin{array}{l}\text { Rotation local flap } \\
\text { reconstruction }\end{array}$ \\
\hline $4 a$ & 1 & Wide excision of tonsil cancer (L) via lateral pharyngotomy approach, MRND (L) & RFFF reconstruction \\
\hline $4 a$ & 0 & Wide excision of tonsil cancer $(R)$ via lateral pharyngotomy approach (R), SOND (R) & RFFF reconstruction \\
\hline $4 a$ & 2 & Transoral robot-assisted wide excision of tonsil cancer (R), RND (R) & None \\
\hline 3 & 2 & Robot assisted transoral oropharyngectomy (R), SND (R) (level II, III, IV) & None \\
\hline $4 a$ & 0 & Transoral robotic surgery $(\mathrm{R})$, tonsillectomy $(\mathrm{L})$ & None \\
\hline 3 & 2 & Lateral oropharyngectomy (R), tonsillectomy (L), SND (R) (level II, III, IV, V) & None \\
\hline $4 a$ & 2 & Wide excision of tonsil cancer (R) (mandible swing approach), extended RND (R) & RFFF reconstruction \\
\hline $4 a$ & 2 & Transoral lateral oropharyngectomy (R), MRND type III (R) & None \\
\hline 3 & 2 & $\begin{array}{l}\text { Transoral lateral oropharyngectomy (R), tonsillectomy (L), extended RND (R), MRND } \\
\text { type III (L) }\end{array}$ & None \\
\hline $4 a$ & 2 & Total glossectomy, MRND type II (R), SND level I, II, III (L), TRAM reconstruction & TRAM free flap reconstruction \\
\hline
\end{tabular}

